\title{
GRAVE OF THE CORDED WARE CULTURE FROM SITE 2 IN ALEKSANDROWICE, KRAKÓW DISTRICT
}

\author{
Kamila Peschel ${ }^{1}$, Piotr WhodarczaK ${ }^{2}$
}

\begin{abstract}
A u th o r s’ a d d r e s s e s: 1 - Atia-Archeologia, e-mail: kpeschel@o2.pl; 2 - Institute of Archaeology and Ethnology PAS, Sławkowska 17, 31-016 Kraków, Poland, e-mail: wlodarczak.piotr@gmail.com, ORCID: 0000-0003-0359-7386.

A b s t r a c t. Graves from the Final Eneolithic period are very common in the loess uplands of western Lesser Poland (Małopolska). Their predominant form is a catacomb construction, related to the Kraków-Sandomierz group of the Corded Ware culture. A grave from Aleksandrowice, Kraków district, belongs to a smaller group of features known from the western border of this region. The grave goods are comprised of a stone battle-axe and a long blade knife, and the bones of the burial have not survived due to unfavourable soil conditions. The grave construction and the type of furnishing allow us to suppose that the grave was originally covered with a barrow. The faceted stone battle-axe with western stylistic connotations (Bohemia, Central Germany) is a unique find. It is the first find of this type in the western part of Lesser Poland. Based on the nature of the finds, the grave can be dated to around 2700-2500 BC, which means to the younger stage of the "barrow phase" of the Corded Ware culture.
\end{abstract}

K e y w o r d s: Eneolithic, Corded Ware culture, Lesser Poland, funeral rite

\section{INTRODUCTION}

Rescue excavations carried out in 2010 at site 2 in Aleksandrowice, commune Zabierzów (AZP 102-55/2), resulted in the discovery of a grave dated to the Final Eneolithic and linked with the Corded Ware culture (CWC). While CWC cemeteries are relatively common in the loess uplands of Western Lesser Poland, they still remain rare finds in the south-western margin of that zone (i.e. in Garb Tenczyński - Tenczynek Hills). The supposed presence of a barrow also places the burial from Aleksandrowice among discoveries significantly enriching the source basis for studies on the Final Eneolithic burial rite in Lesser Poland. The artefacts recovered from the grave, most likely grave goods offered to the deceased, are unique as well.

Stretching over an area of more than 30 hectares, site 2 in Aleksandrowice is actually a vast area concealing, in different places, an accumulated record of a range of episodes of prehistoric occupation. The site occupies a stretch of loess-covered land 
in the forks of the Aleksandrówka and Brzoskwinka streams, slightly elevated above the bottoms of their valleys. From the west, the site is closed by steep slopes of the hills forming Garb Tenczyński (Fig. 1).

Archaeological excavations were carried out in various locations within the vast site 2 in many stages and by a number of contractors, in connection with various construction projects (Fig. 1). They brought about discoveries of materials linked with various periods of prehistory, depending on the part of the site. Materials from the La Tène and Roman periods were predominant in the northern part (NAGLIK 2000), while further to the south materials dated to the Neolithic (mainly the LBK and Malice cultures) and Bronze Age (Lusatian culture) prevailed. Flint workshop areas were identified within the site, including Late Palaeolithic flint scatters. Other interesting discoveries were single graves of Final Eneolithic date, attributed to CWC communities. The grave discussed below was discovered during research carried out by the archaeological firm Atia-archeologia (with Kamila Peschel as the director of excavations) in connection with the construction of a mixed-use office/warehouse building. The excavations encompassed an area of $20600 \mathrm{~m}^{2}$ in the southern part of the site (Fig. 1). The CWC grave was discovered in the middle of the explored area (Fig. 2), and no other Final Eneolithic finds were recorded.

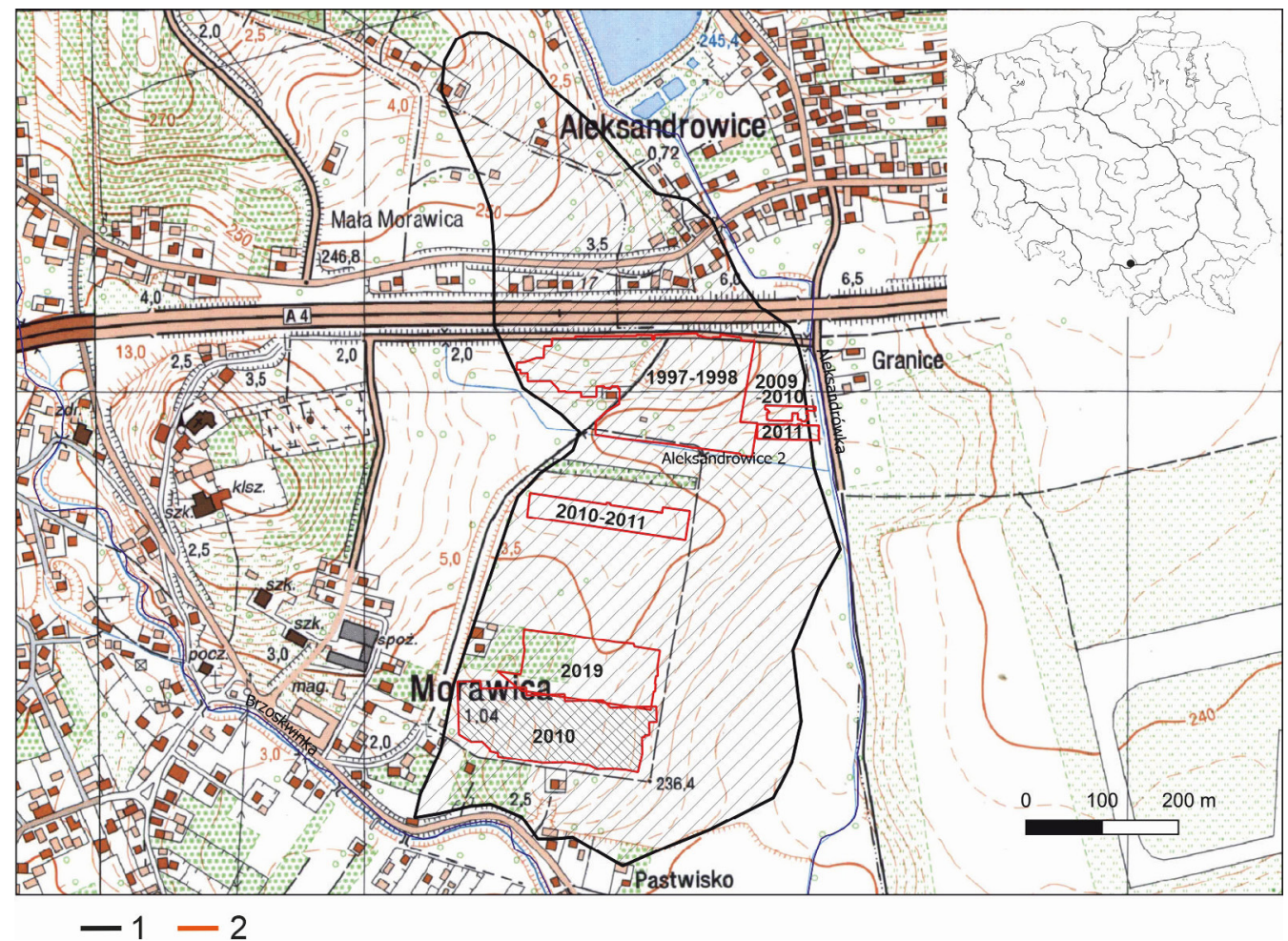

Fig. 1. Location of the trench from 2010 in site 2 in Aleksandrowice, comm. Zabierzów (hatched area). Designed by M. Zajac. 1 - range of the site, 2 - boundaries of archaeological trenches 

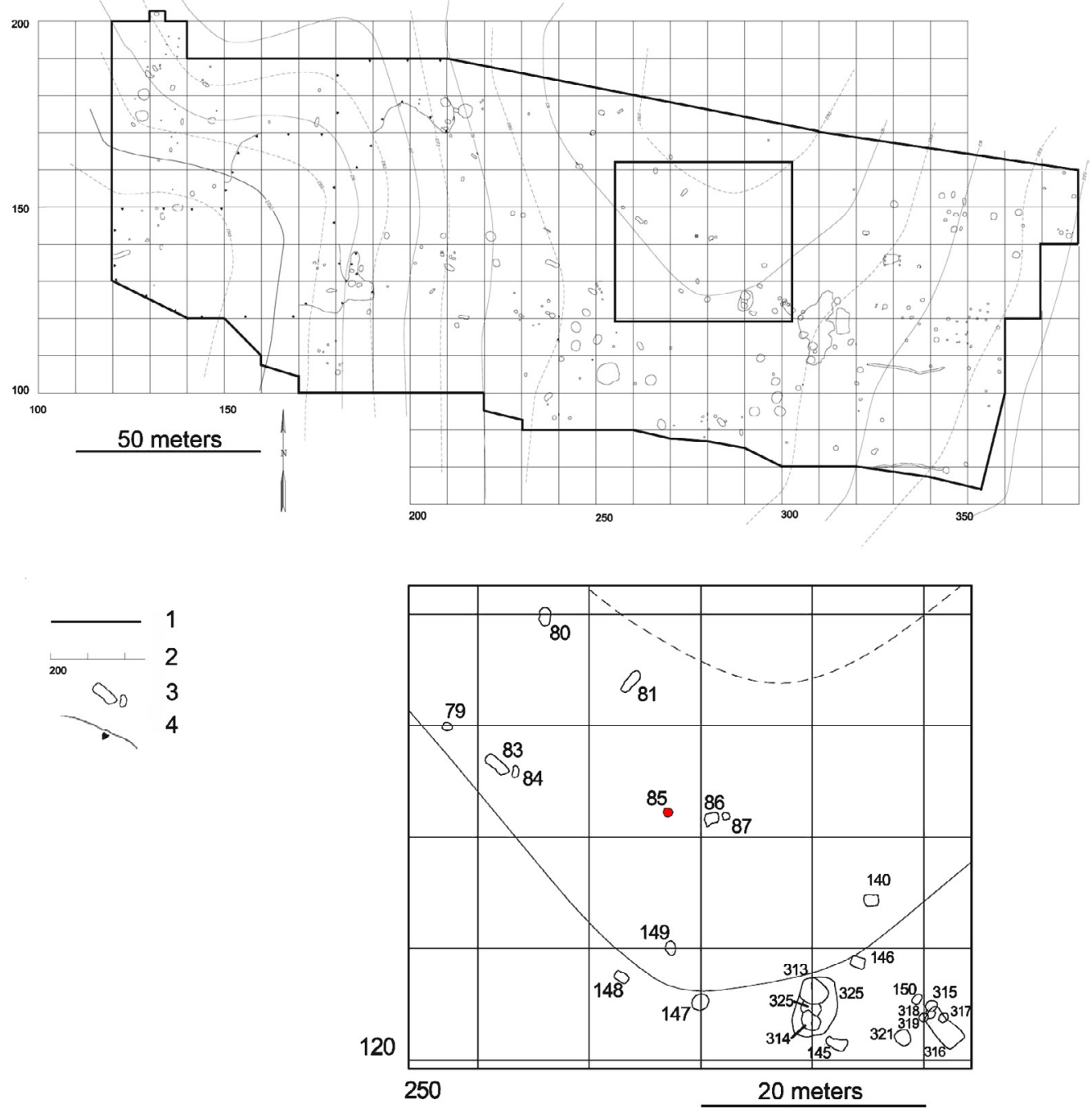

Fig. 2. Aleksandrowice, comm. Zabierzów, site 2. Plan of the explored area with the location of feature 85. Designed by K. Peschel. 1 - boundaries of archaeological trenches, 2 - excavation grid, 3 - archaeological features, 4 - boundaries of the cultural layer

\section{GRAVE DESCRIPTION}

The grave, designated in the field documentation as "feature 85", was discovered immediately beneath the bottom of the humus layer. Its outline was poorly discernible and resembled an oval approx. $120 \times 90 \mathrm{~cm}$ in size. The outline only became more legible $40 \mathrm{~cm}$ deeper, where it could be more precisely described. At that depth, the grave cut had the shape of an oval clearly flattened from the SW, with dimensions of $170 \times 30 \mathrm{~cm}$ (Fig. 3: A). The fill was heterogenous and consisted of grey-brown soil mixed with lumps of yellow loess. A distinctly darker layer was recorded, forming 


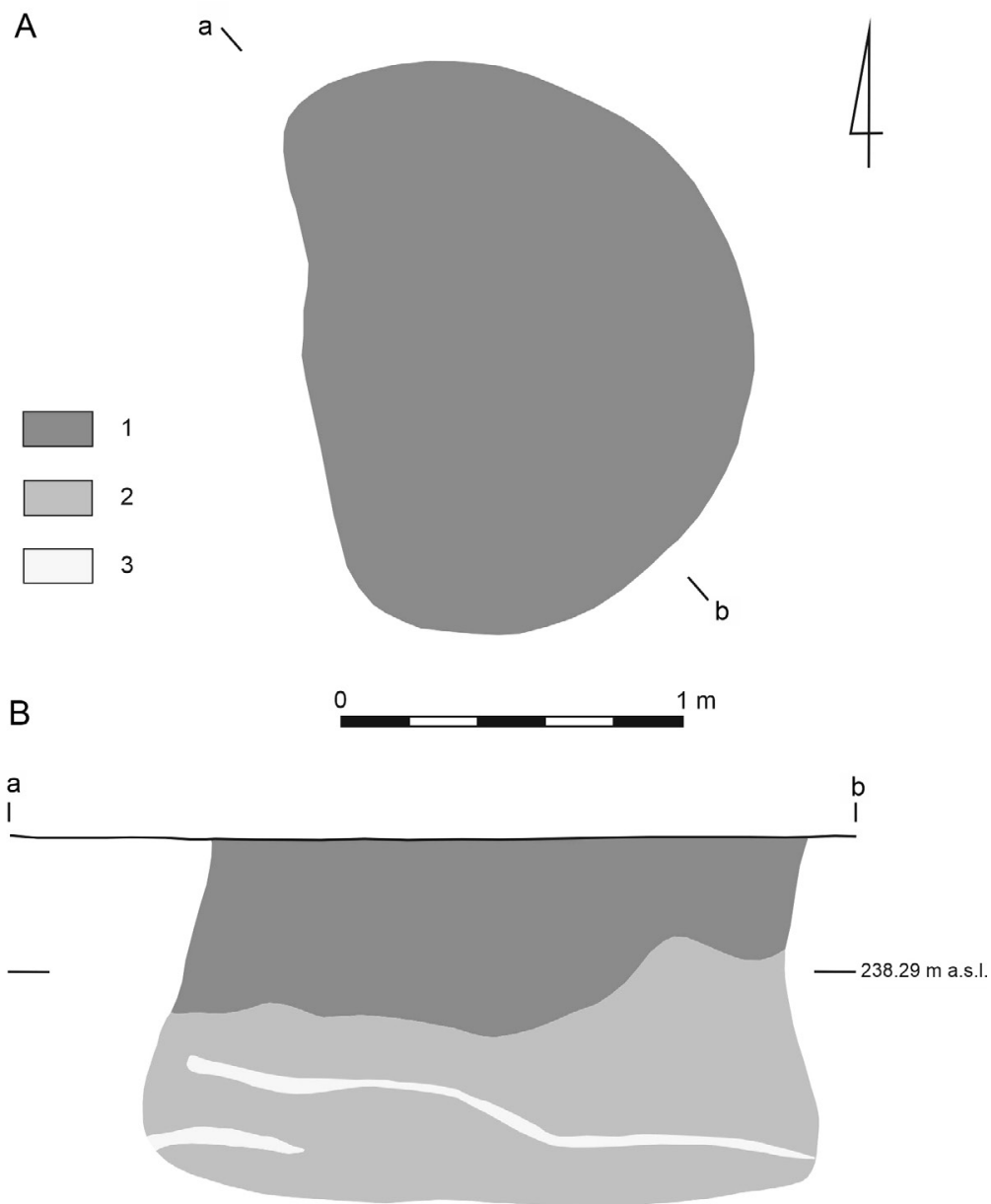

Fig. 3. Aleksandrowice, comm. Zabierzów, site 2. Feature 85: A - plan at a depth of $70 \mathrm{~cm}, \mathrm{~B}$ - cross-section. Drawn by K. Juszczyk. 1 - dark, humic soil of grey-brown colour, 2 - light, heterogenous soil of grey-brown colour, mixed with yellow loess and dark grey-brown soil, 3 - yellow loess

a hollow in the upper part of the pit. In cross-section, the pit resembled a trapezium (Figs 3: B; 4), with a flat bottom at a depth of $140 \mathrm{~cm}$ beneath the ground surface. It was at that depth that a stone battle axe and a blade tool were found (their precise locations were not recorded). No traces of burial were identified.

Description of the inventory:

1. Pentagonal battle axe with faceted sides, made from grey siltstone (raw material identification by Dr Marek Doktor from the Institute of Geology PAS), covered with a thick patina layer of beige colour. Symmetrical blade. Oval, slightly concave butt. The main surfaces are flat. The side surfaces bear slightly marked traces of regular faceting, more legible in the butt part. The facets form 6 or 7 narrow, parallel surfaces. Dimensions: length $-121 \mathrm{~mm}$, height $-27 \mathrm{~mm}$, width $-53 \mathrm{~mm}$, blade width $-27 \mathrm{~mm}$, butt dimensions $-27 \times 22 \mathrm{~mm}$, hole diameter $-19 \mathrm{~mm}$ (Figs 5, 6). 


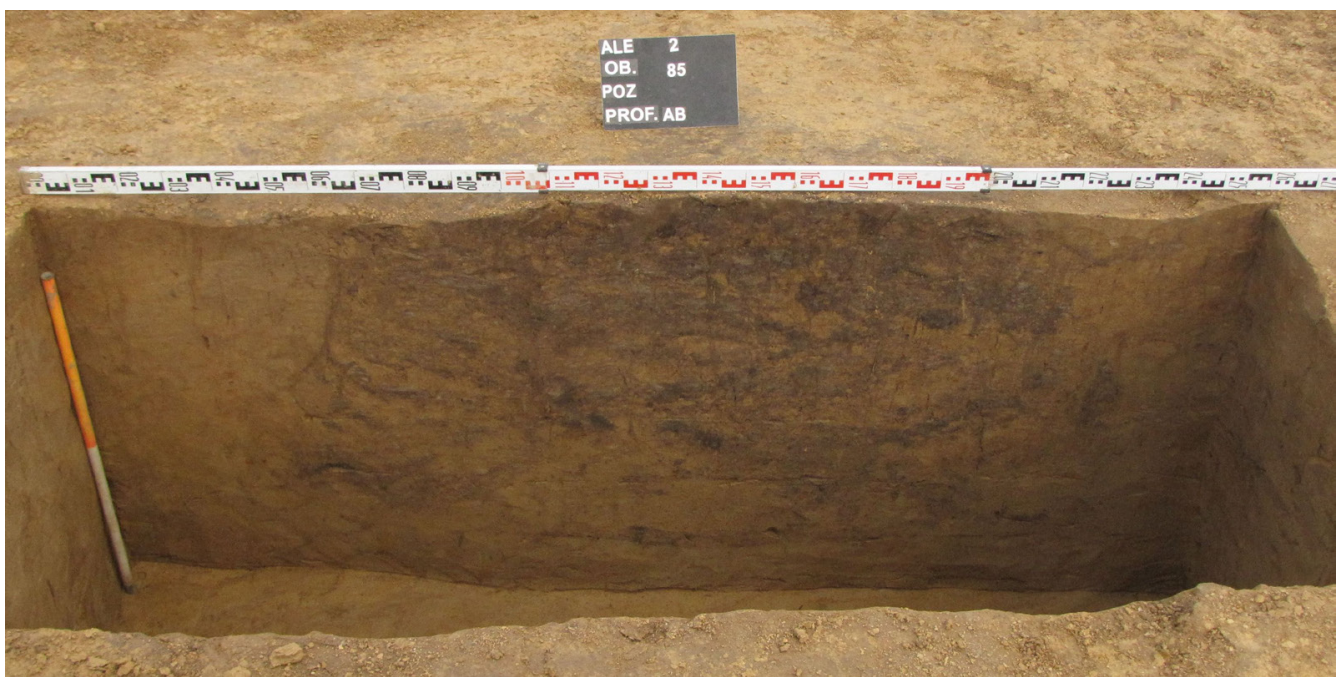

Fig. 4. Aleksandrowice, comm. Zabierzów, site 2. Cross-section of feature 85 . Photo by G. Bąk-Pryc

2. Retouched blade of Cretaceous Volhynian flint, made on a massive blank removed from a regular single-platform core with a prepared striking platform. The negative side is partially cortical. The regular, flat, semi-abrupt retouch, extending partially to the dorsal side, covers both sides over nearly their entire lengths and the top part. The side edges are slightly polished, with use-wear traces. Dimensions: $126 \times 32 \times 8 \mathrm{~mm}$ (Fig. 7).

\section{ANALYTICAL REMARKS}

The photographic and drawing documentation does not allow the construction of the analysed grave to be unambiguously determined. The problems stem in part from unfavourable soil conditions which make it difficult to identify the grave cut's boundaries and to discern layers within the fill. Another factor is that the nature of the feature was not identified during the exploration. In addition, the type of the grave construction may in itself have added to the problems. Final Eneolithic graves were typically established as empty chambers, either pits (in barrow graves from the older phase of CWC) or niches (prevailing in cemeteries from the younger phase). Their fills consist of many layers, including the soil that fell off from the collapsing walls. Therefore, rather than the original outlines of graves, the shapes recorded during excavations in the upper levels are sometimes the irregular outlines of collapsed grave chambers. Feature 85 from Aleksandrowice meets these characteristics. In the upper part, the shape in plan was an oval with poorly discernible boundaries. In the lower part it had a sub-rectangular shape with the longer sides oriented along the NNW-SSE axis. These observations are not sufficient to determine whether this was a pit or a niche. The oval outline in the upper part and the cross-section seem to point more to a niche grave. On the other hand, the grave goods, discussed further in the text, find more analogies among barrow graves, in which burials 

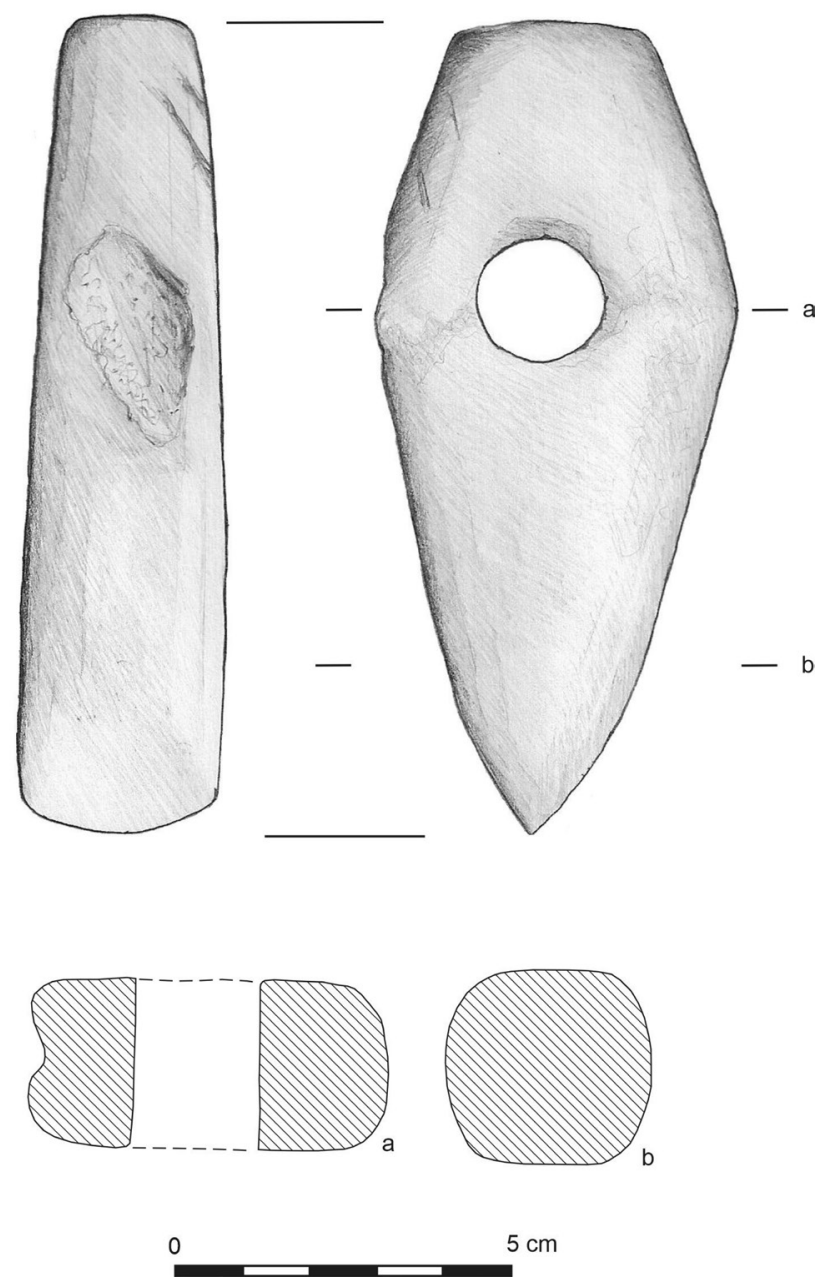

Fig. 5. Aleksandrowice, comm. Zabierzów, site 2. Grave goods from feature 85: battle axe. Illustrated by K. Peschel

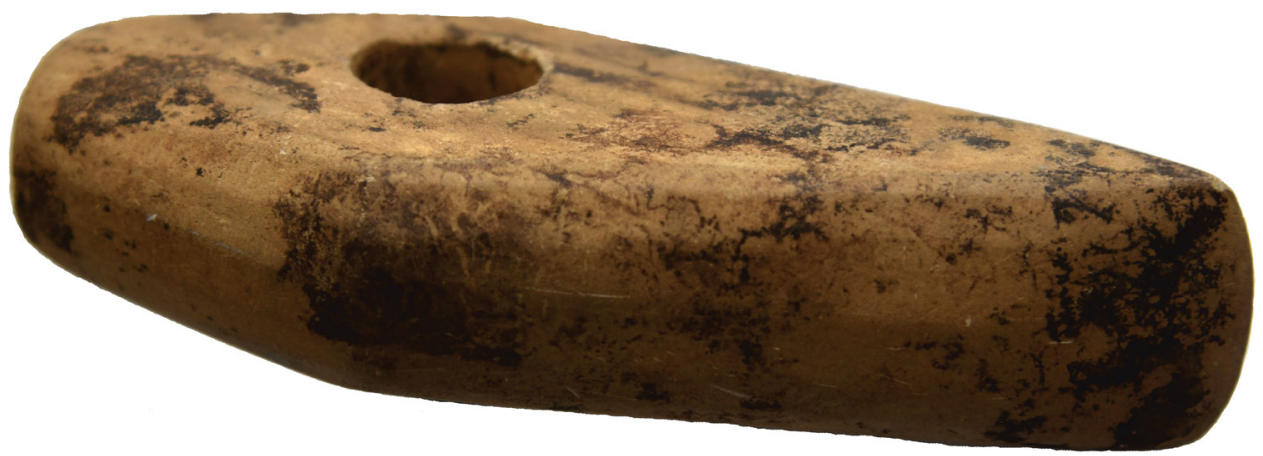

Fig. 6. Aleksandrowice, comm. Zabierzów, site 2. Battle axe. Photo by P. Włodarczak 


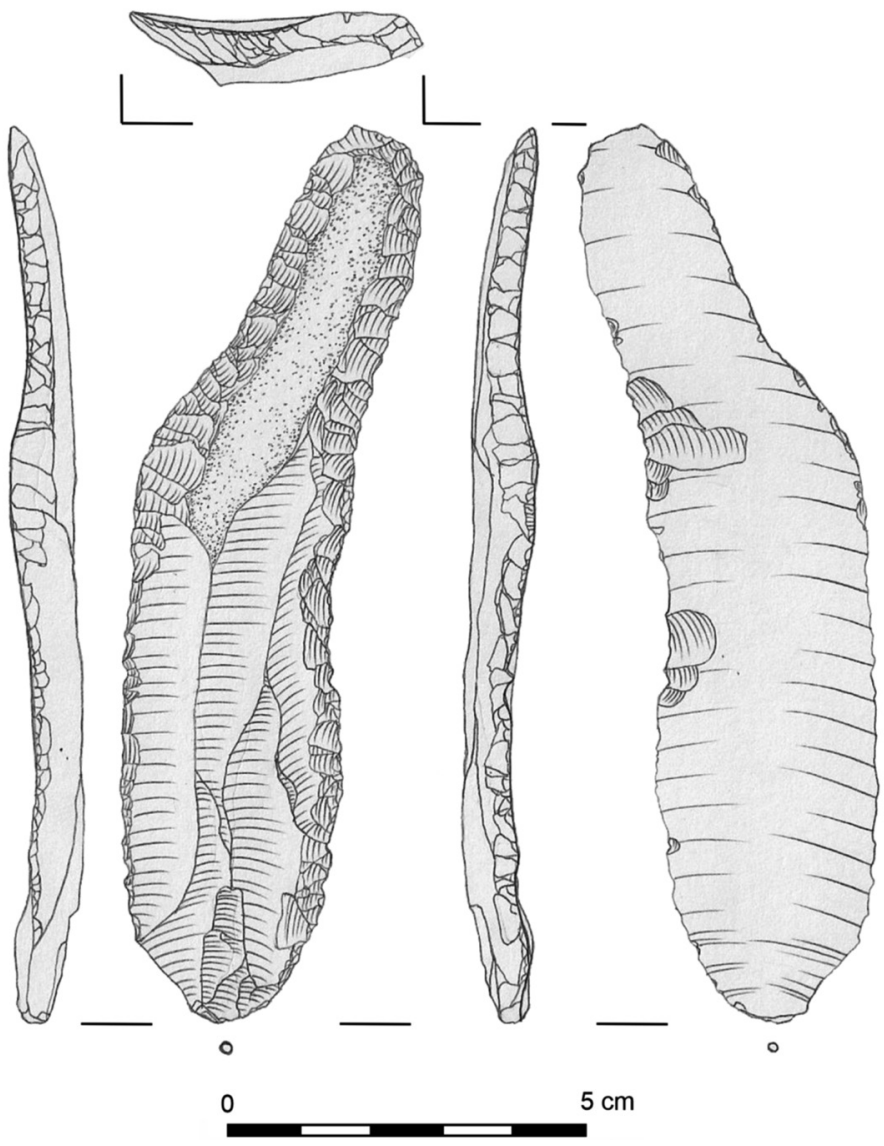

Fig. 7. Aleksandrowice, comm. Zabierzów, site 2. Grave goods from feature 85: retouched blade of Volhynian flint. Illustrated by K. Peschel

were usually placed in a rectangular pit (more often) or an oval pit (less often). A niche burial covered with a barrow cannot be ruled out, either (see e.g. Miernów II, grave 2, or Pałecznica, grave 1 - KeMPISTY 1978: 18-22; LiguZIŃSKA-KRUK 1989: 116-119).

The characteristics of feature 85 and the nature of the objects discovered in its bottom part (unfortunately, their precise locations have not been recorded) indicate that the feature was undoubtedly a grave. The burial has not survived, most likely due to the natural decomposition of bones in the acidic soil. Neither have human nor animal bones been recorded in other features explored in the Aleksandrowice site. The discovery of a stone battle axe and a long, regular blade insert at the bottom of feature 85 has unequivocally determined the feature's function, indicating at the same time the adult age and male sex of the deceased. The absence of a ceramic vessel, which is a rare trait among Final Eneolithic burials from western Lesser Poland, is telling in this context. Aceramic inventories are better-represented in the still small group of barrow graves linked with the older phase of CWC (WŁODARCZAK 2000). In the later period, meaning in cemeteries attributed to the Kraków-Sandomierz group, adult burials with no ceramic furnishings 
are a less common phenomenon. Nevertheless, 32 such burials have been discovered to date, and this number includes burials of men furnished with weapons and tools - e.g. Malice Kościelne, grave 14A (BARGIEŁ et al. 2001: 233-237) or Złota, site 6, grave 15 (FLOREK, ZAKośCIELNA 2006: 43-47). Importantly, the absence of pottery has been recorded more often in male burials than in female ones (cf. WŁODARCZAK 2006: 69).

The battle axe from Aleksandrowice (Figs 5,6) is the first faceted specimen discovered in the context of a CWC grave in western Lesser Poland. It stands out from the most common types known from the Kraków-Sandomierz group in terms of shape as well. Its characteristic morphological traits include the rhomboidal (also called pentagonal) shape in top view, with sharply marked side edges, the hole moved distinctly towards the butt, and a short, symmetrical blade. Weapons of this type are one of the classic variants of CWC battle axes in Central Germany. They are also known from north-western Germany (variant $2 \mathrm{~b}$ - BRANDT 1967: 77) and, in smaller number, north-eastern Germany (JACOBS 1991: 128, Taf. 32: 6). Numerous faceted battle axes are known from Bohemia where, as in Central Germany, they should be considered a leading type in the local CWC (type FHA = facetierte Hammeräxte - BUCHVALDEK 1986). Among them, variant FHA 2a (BUCHVALDEK 1967: 52, 53), distinguished by its low height and the symmetry of its side view, seems to be an analogy for the specimen from Aleksandrowice.

In typological terms, the described artefact generally refers to battle axes from the "western" groups of CWC, characterised by distinct edges and reduced butt parts, such as the Uecker type or some battle axes of the Bohemian type (BUCHVALDEK 1962, 1964; SCHROEDER 1951). The reduced length of the part between the hole and the butt is a trait typical of later phases of CWC development, which is evidenced by a sizeable group of "northern" forms of type K (GLOB 1945: 45-49), including variant K8, closest to the Aleksandrowice battle axe (STRUVE 1955: 25, Taf. 1). Rhomboidal forms with reduced butt parts usually link with the late phase of CWC. However, somewhat similar specimens (although usually much higher) also occur in much later, Bronze Age cultural contexts (e.g. Frense 2013).

Faceted battle axes of types $2 \mathrm{a}$ and $2 \mathrm{~b}$ are most often placed in a chronological horizon preceding the "phase" of the K type, although a parallel occurrence of stylistically very different trends has also been noted (e.g. BUCHVALDEK 1986: 106). It has been emphasised that the faceted artefacts in question are distinctly younger than the Old Corded horizon (= phase $1=$ horizon A).

Another diagnostic feature of the Aleksandrowice battle axe is its narrow blade, with its length more or less the same as the artefact's height. This corresponds to the style represented by some faceted battle axes from Bohemia and Germany, but it is a trait foreign to Lesser Poland, where battle axes with long, typically asymmetrical blades prevail. In the classic approach, battle axes with narrow blades are one of the two leading forms of faceted battle axes in Central Germany (type 2 - BRANDT 1967: 77).

Various aspects of faceted battle axes were recently addressed in a publication of a CWC grave from site 13 in Iwiny in Lower Silesia (CHMIELEWSKI, KRUPSKI 2019). Presented in that study the map of distribution of such artefacts shows they are virtually absent from western Lesser Poland (ChMielewski, Krupski 2019: 80, fig. 10). From 
the entire area of south-eastern Poland only one find of that type is included on the map, a battle axe from grave 1 in Lublin Sławinek (PoLAŃSKA 2016: 311, 320, fig. 4: 3). Importantly, Chmielewski and Krupski noted that faceted battle axes from the territory to the east of the Oder River are not a homogeneous group (CHMIELEWSKI, KRUPSKI 2019: 81-83). Faceting is not limited to battle axe forms showing western (Central German) connections. This is well-illustrated by the aforementioned artefact from Lublin Slawinek, which represents type H, typical of Lesser Poland (WŁODARCZAK 2006: 35, 36). In light of the above, the battle axe from Aleksandrowice should be seen as a typical faceted form, imported from the "western" groups of CWC. This is indicated by both its form and the manner of its surface treatment.

Two more faceted battle axes from western Lesser Poland are mentioned in the literature. A specimen from Raciborsko near Wieliczka, a stray find from the early $20^{\text {th }}$ century (DEMETRYKIEWICZ 1908: 12; MACHNIK 1961: 16), was described by MARIA CABALSKa (1960: 193, 243) as a faceted form of the "Thuringian type". However, this artefact lacks distinct traits typical of Central Germany, instead being an example of type D (WŁodARCZAK 2006), quite common in Lesser Poland assemblages (see LiwOCH 2018: pl. VI: 7). Moreover, this battle axe does not reveal traces of faceting, so it cannot be considered an analogy to the find from Aleksandrowice. The second example mentioned in the literature is a butt part of a battle axe with clearly marked facets from site 2 in Raszówek (near Miechów) (GórSKI 2000: 211, Abb. 3: 1). The treatment of the surface is much different here than in the slightly faceted battle axe from Aleksandrowice ( $c f$. e.g. KEGLER-GRAIEWSKI 2007: 226). The fragmentary preservation of the artefact makes its reliable typological identification, and even its taxonomic and chronological determination, impossible. Assuming it was a Final Eneolithic battle axe, it would link with the late phase of CWC and would be - like the artefact from Aleksandrowice - an import from the west.

Although the form represented by the Aleksandrowice battle axe may suggest its origin as Central Germany, the analysis of the raw material from which it was made leads to slightly different conclusions. The artefact was made from siltstone, a raw material most likely originating from Carpathian flysch. In this context, it is worth noting that such rocks were used for making ground stone tools by CWC communities in Moravia (P̌̌ICHYSTAL 1999: 219; 2009: 212-214). Importantly, faceted battle axes, including pentagonal specimens akin to the one from Aleksandrowice, are known from that region (ŠEBELA 1999: Pl. 13: 3, 143: 4, 163: 2, 166: 6). They occur in the northern part of Moravia as well, which means in an area exposed to contact with western Lesser Poland (e.g. PeŠKA 2013: 145, obr. 97: 8). This makes the territories to the south-west of Lesser Poland the most likely place of origin for the Aleksandrowice artefact, although a fully precise identification of the provenance of the siltstone used for its manufacture requires more detailed specialist analyses in future.

The retouched blade (Fig. 7) represents an asymmetrical form characteristic of CWC assemblages, being an example of a typical "flame-shaped knife" (VALDENowAK 2000). It belongs to a group of tools made on large, massive blades (more than $10 \mathrm{~cm}$ in length) which, along with less regularly retouched blades and unretouched 
blades, have been included into the functional category of "long knife blade inserts" (WŁODARCZAK 2006: 30,31). They are particularly characteristic of central burials in barrow graves. In western Lesser Poland they have been found in Gabultów (grave 1; GóRSKI, JAROSZ 2006: 408, fig. 7: 2), Kocmyrzów (grave 1; unpublished research by K. Tunia), Koniusza (grave 1; Tunia 1979: 70, fig. 18: e), and Miernów (barrow 1, grave 4; KEMPISTY 1967: 157, fig. 7). They have also been discovered in a few shaft and niche graves, examples being feature 3 from Kolosy (KeMPISTY 1978: 241, fig. 284: 2) and grave 138 from Żerniki Górne (Kempisty, WŁodARCZAK 2000: 97, fig. 64: 7).

The flint tool was made of Cretaceous flint of eastern provenance, conventionally described as "Volhynian flint". This raw material is rarely recorded in western Lesser Poland. With respect to blade tools, only the abovementioned retouched blade from Kolosy was made from such flint. Similar metric and technological characteristics can be found in a retouched blade of Jurassic flint, discovered in a (barrow?) grave from Kietrz on the Głubczyce Plateau (Gedl 1974; Valde-NowaK 2000: 471, Abb. 2: 1). Analogical long knife-like forms are more frequent in grave assemblages in the eastern part of Lesser Poland and in western Ukraine. Examples that can be considered close analogies to Aleksandrowice include specimens from the barrow in Lipie and barrow 2/98 in Średnia (VALDE-NowAK 2000: 471, 473, Abb. 2: 3, 3: 3).

Similar blade tools, although made primarily of Świeciechów flint, are characteristic of the late Globular Amphora Culture (GAC), a perfect illustration being the inventory of grave 523 from Koszyce (BudzISZEwsKi, GRużDź 2013: 163-169). The authors who published this inventory noticed the use of the punch technique, and distinguished such tools from blades removed using the pressure technique, which prevail in the GAC. The artefacts discovered in CWC and GAC graves from the first half of the 3rd millennium BC point to a custom of furnishing the deceased with a knife provided with a long, continuous flint insert. The insert was probably attached sticking upwards, as it is in daggers. This makes these tools clearly different from the knives prevailing in the Kraków-Sandomierz group (ca. 2550-2300 BC), in which a much shorter insert was attached lengthways in a groove made in a short, wooden handle (WŁODARCZAK 2006: 31).

A range of rescue excavations carried out in Aleksandrowice site 2 brought about the discovery of two more graves reliably associated with the CWC (MAZUR 2011; MiCYK et al. 2020). Only one of them, feature 369 discovered in 2019, has been published to date (MiCYK et al. 2020). It was situated approx. $100 \mathrm{~m}$ from the grave discussed in this paper. The lack of description and the available documentation (comprising only photographs of the grave fragments) make it impossible to identify the type of construction. However, when analysing the plan of the 2019 excavations, features 346 and 389 discovered in the vicinity of the CWC grave attract particular attention (MiCYK et al. 2020: fig. 3). These are small, rectangular timber box constructions placed in oval pits, oriented along the N-S axis (MicyK et al. 2020: 261, 262, figs 11, 12). They have been interpreted by the author of the research as "probably wells" (MICYK et al. 2020: 259), which seems highly unlikely given the construction and depth of these pits. These features find very good analogies among Final Eneolithic barrow graves, rather than among wells. Graves under barrows are usually much larger, sometimes reaching approx. $3 \times 2 \mathrm{~m}$ in size, but 
smaller graves, comparable with the features from Aleksandrowice, are known as well. Good analogies nearby include Lelowice (site 4, feature 9; RoDAK 2002: 127, fig. 7) and Modlnica (site 5, feature 89; WŁODARCZAK et al. 2011: 369, pl. 20: A). The small size of some graves under barrows is probably connected with the fact that they are child burials, which has been demonstrated in Lelowice by the anthropological analysis of human remains. Thus, features 346 and 389 are likely associated with two small, Final Eneolithic barrows erected over child burials.

A grave of analogical construction (as yet unpublished) indicative of a central burial under a barrow was also discovered in another part of the site during excavations carried out in 1998 (feature 1424; CzEKAJ-ZASTAWNY 2000). It resembled the two features mentioned above (346 and 389) in terms of dimensions, but differed in terms of orientation (NW-SE). The grave has been dated to the Final Eneolithic based on its constructional traits alone, as it produced no artefacts from that period.

The discoveries presented above document the presence of a vast sepulchral-ceremonial area within site 2 in Aleksandrowice, which was used by Final Eneolithic communities. Its older elements were barrows, and younger elements include graves dug into the mounds or placed near them. The CWC grave which is the focus of this paper was discovered in the southern part of this area. The location of the entire complex - on a loess promontory towering over the valleys of watercourses - is typical for CWC sites in the loess uplands of western Lesser Poland (KRUK 1973: 62, 63).

\section{CONCLUSIONS}

The above stylistic, technological, and raw material references reveal an interesting discrepancy in terms of cultural-geographical connections between the battle axe and the blade tool from the Aleksandrowice grave. Neither of these artefacts find good analogies in the quite numerous cemeteries of western Lesser Poland. They are foreign forms here: the battle axe represents a style characteristic of western CWC groups, while the knife testifies to contacts with territories to the east of the Kraków region. This situation highlights a rule that can be observed in the funeral rituals of CWC in Lesser Poland: raw materials and provenance played a significant role in the choice of prestigious artefacts to be put to grave (WŁODARCZAK 2017: 321). This explains why grave assemblages often contain objects originating from distant areas.

Based on the typological data, grave 85 from Aleksandrowice belongs to the turn of the Old Corded period (= barrow period $=$ phase I) and the younger period (= niche grave phase $=$ stage II/IIIA acc. to WŁODARCZAK 2006). This corresponds with the close of the first half of the $3^{\text {rd }}$ millennium BC (generally around 2650/2600-2500 BC).

In light of the above dating, the available data do not allow the construction of the grave to be fully reliably identified. A niche construction is likely, but far from certain. Furthermore, one cannot rule out that the grave was originally covered with a small barrow, which was a common practice in that period among the Final Eneolithic communities in Lesser Poland. 
ACKNOWLEDGEMENTS. The authors would like to thank Ryszard Naglik and Mirosław Zając for preparing the overall plan of the site, showing trenches explored in different seasons. The authors are grateful to Radosław Liwoch, Marzena Woźny, and Albert Zastawny from the Archaeological Museum in Kraków for facilitating access to the source data. The authors thank Professor Jerzy Libera for his help in identifying the raw material.

\section{REFERENCES}

BARgiee B., Libera J,. FloreK M., 2001. Groby ludności kultury ceramiki sznurowej i mierzanowickiej ze stanowiska 1 w Malicach Kościelnych, woj. świętokrzyskie. Sprawozdania Archeologiczne 53: 231-259.

BRANDT K. H., 1967. Studien über steinerne Äxte und Beile der jüngeren Steinzeit und der Stein-Kupferzeit Nordwestdeutschlands. Münstersche Beiträge zur Vorgeschichtsforschung 2. Hildesheim, Lax.

BuCHVALdeK M., 1962. Sekeromlat českého typu. Sborník Československé společnosti archeologické 2: 225-234.

BuchVAldeK M., 1964. K eneolitickým sekeromlatům v Čechách. Musaica 4: 2-14, Tables 1-6.

Buchvaldek M., 1967. Die Schnurkeramik in Böhmen. Acta Universitatis Carolinae. Philosophica et historica. Monographia 19. Praga, Universita Karlova.

BuchvaldeK M., 1986. Kultura se šn̆ůrovou keramikou ve střední Evropě. Praehistorica 12. Praha, Univerzita Karlova.

Budziszewski J., Grużdź W., 2013. O technikach i metodach krzemieniarskich. In: M. M. Przybyła, A. Szczepanek, P. Włodarczak (Eds), Koszyce, stanowisko 3. Przemoc i rytuał u schyłku neolitu. Ocalone Dziedzictwo Archeologiczne 4. Kraków-Pękowice: Stowarzyszenie Archeologów Terenowych STATER, Wydawnictwo i Pracownia Archeologiczna Profil-Archeo: 161-184.

CabalsKa M., 1960. Kultura pucharów lejowatych. Materiały. In: R. Jamka (Ed.), Pradzieje powiatu krakowskiego. Tom I. Zeszyty Naukowe Uniwersytetu Jagiellońskiego. Prace Archeologiczne 1. Kraków, Wydawnictwo UJ: 143-234.

ChMielewsKi T., KRUPSKI M., 2019. Zespół kamiennych toporów ze stanowiska Iwiny 13, woj. dolnośląskie. Glosa w kwestii wschodniego zasięgu występowania fasetowanych toporów kultury ceramiki sznurowej. Fontes Archaeologici Posnanienses 55: 65-100.

Czekaj-Zastawny A., 2000. Aleksandrowice stanowisko 2, 3, gm. Zabierzów, woj. małopolskie. Neolit (manuscript). Kraków, Krakowski Zespół do Badań Autostrad.

Demetrykiewicz W., 1908. Materiały Antropologiczno-Archeologiczne i Etnograficzne 10: 12.

FloreK M., ZaKościelna A., 2006. Wyniki badań ratowniczych na stanowisku 6 w Złotej, pow. sandomierski, w latach 2002-2004. Archeologia Polski Środkowowschodniej 8: 41-56.

FreHSE D., 2013. Die Fünfeckäxte aus dem Gebiet der heutigen sächsischen Oberlausitz. Veröffentlichungen Museums Westlausitz Kamenz 31: 3-16.

GedL M., 1974. Neolityczny grób szkieletowy z Kietrza, pow. Głubczyce. Sprawozdania Archeologiczne 26: $35-40$.

GLoв P. V., 1945. Studier over den jyske Enkeltgravskultur. Aarborger for nordisk Oldkyndighed og Historie (1944). Kobenhavn: 15-64.

GóRSKI J., 2000. Übersicht über das neueste Fundgut des Endneolithikums und der Frühbronzezeit aus dem Lößgebiet westlichen Kleinpolens. In: S. Kadrow (Ed.), A turning of ages. Im Wandel der Zeiten. Jubilee book dedicated to Professor Jan Machnik on his 70th anniversary. Kraków, Instytut Archeologii i Etnologii PAN: 207-223. 
GóRSKI J., JAROSZ P., 2006. Cemetery of the Corded Ware and the Trzciniec cultures in Giebułtów/Cmentarzysko kultury ceramiki sznurowej i trzcinieckiej w Gabułtowie. Sprawozdania Archeologiczne 58: 431-434/434-451.

JACOBS J., 1991. Die Einzelgrabkultur in Mecklenburg-Vorpommern. Beiträge zur Ur- und Frühgeschichte Mecklenburg-Vorpommerns 24. Schwerin, Landesamt für Kultur und Denkmalpflege.

Kegler-Graiewski N., 2007. Beile - Äxte - Mahlsteine. Zur Rohmaterialversorgung im Jung- und Spätneolithikum Nordhessens. Dissertation im Fach Ur- und Frühgeschichte der Philosophischen Fakultät der Universität zu Köln. Köln.

Kempisty A., 1967. Wyniki badań kopca I w Miernowie pow. Pińczów. In: J. Fellmann (Ed.), Metodyka naukowo-techniczna badań archeologicznych i antropologicznych. Warszawa, Państwowe Wydawnictwo Naukowe: $147-175$.

KEMPISTy A., 1978. Schyłek neolitu i początek epoki brązu na Wyżynie Małopolskiej w świetle badan nad kopcami. Warszawa, Wydawnictwo UW.

Kempisty A., Wøodarczak P., 2000. Cemetery of the Corded Ware culture in Żerniki Górne. Światowit Supplement Series P: Prehistory and Middle Ages 5. Warsaw, Instytut Archeologii UW.

KRUK J., 1973. Studia osadnicze nad neolitem wyżyn lessowych. Wrocław-Warszawa-Kraków-Gdańsk, Zakład Narodowy im. Ossolińskich.

LiguZIŃSKA-KRUK Z., 1989. Kurhan kultury ceramiki sznurowej w Pałecznicy, woj. Kielce. Sprawozdania Archeologiczne 40: 113-127.

LıwOch R., 2018. Zabytki archeologiczne z „Wystawy starożytności i zabytków sztuki” urządzonej przez Cesarsko-Królewskie Towarzystwo Naukowe w Krakowie (1858-1859 r.). In: J. Górski (Ed.), Od kolekcjonerstwa do muzealnictwa. 160-lecie pierwszej wystawy w Muzeum Archeologicznym w Krakowie. Kraków, Wydawnictwo Pracownia Archeologiczna Profil-Archeo: 41-119.

MaCHNiK J., 1961. Kultura ceramiki sznurowej. In: S. Nosek (ed.), Pradzieje powiatu krakowskiego. Tom 2. Zeszyty Naukowe UJ, Prace Archeologiczne 2. Kraków, Uniwersytet Jagielloński: 5-36.

MAZUR K., 2011. Sprawozdanie z ratowniczych badań wykopaliskowych przeprowadzonych na stanowisku $\mathrm{nr} 2 \mathrm{w}$ Aleksandrowicach, gm. Zabierzow (obręb geodezyjny Morawica, działki nr 873/6, 874/2 i 875/6) w latach 2010-2011 [manuscript]. Kraków.

Micyk P., Szarek Ł., Zakrzeńska J., ChowanieC J., Nowak M., 2020. Nowe dane o zasiedleniu stanowiska $\mathrm{nr} 2 \mathrm{w}$ Aleksandrowicach (pow. krakowski) w paleolicie, neolicie i wczesnej epoce żelaza, w świetle wykopalisk przeprowadzonych w 2019 roku. In: M. Dębiec, T. Saile (Eds), A planitiebus usque ad montes. Studia archaeologica Andreae Pelisiak vitae anno sexagesimo quinto oblata. Rzeszów, Wydawnictwo Uniwersytetu Reszowskiego: 251-300.

NAGLIK R., 2000. Archeologiczne badania ratownicze na trasie autostrady A-4 w zachodniej Małopolsce. Z otchłani wieków 2/2000: 44-49.

PEŠKa J., 2013. Morava na konci eneolitu. Olomouc, Akademické Nakladelství CERM, s.r.o.

PolaŃSKA M., 2016. Cmentarzysko kultury ceramiki sznurowej na wielokulturowym stanowisku 1-2 w Lublinie-Sławinku. In: P. Jarosz, J. Libera, P. Włodarczak (Eds), Schyłek neolitu na Wyżynie Lubelskiej. Kraków, Instytut Archeologii i Etnologii PAN: 307-328.

PřIChYSTAL A., 1999. The petrographic investigation of stone artefacts of the Corded Ware culture in Moravia and the adjacent part of Silesia. In: L. Šebela (Ed.), The Corded Ware culture in Moravia and in the adjacent part of Silesia (catalogue). Brno, Archeologický Ústav Akademie Věd České Republiky v Brně: 213-223.

Přichystal A., 2009. Kamenné suroviny v pravěku východní části střední Evropy. Brno, Masarykova Univerzita. 
RoDAK T., 2002. Wyniki badań przeprowadzonych na stanowisku 4 w Lelowicach gm Radziemice, woj. małopolskie. Materiały Archeologiczne 33: 123-136.

Schroeder R., 1951. Die Nordgruppe der Oderschnurkeramik. Vorgeschichtliche Forschungen 14. Berlin, Walter de Gruyter \& Co.

Struve K. W., 1955. Die Einzelgrabkultur in Schleswig-Holstein und ihre kontinentalen Beziehungen. Offa-Bucher, Neue Folge 11. Neumunster, Karl Wachholtz Verlag.

ŠEbela L., 1999. The Corded Ware culture in Moravia and in the adjacent part of Silesia (catalogue). Brno, Archeologický Ústav Akademie Věd České Republiky v Brně.

Tunia K., 1979. Cmentarzysko kultury ceramiki sznurowej w Koniuszy, woj. Kraków. Sprawozdania Archeologiczne 31: 47-77.

VALDE-NowAK P., 2000. Flammförmige Messer der Schnurkeramikkultur. In: S. Kadrow (Ed.), A turning of ages. Im Wandel der Zeiten. Jubilee book dedicated to Professor Jan Machnik on his 70th anniversary. Kraków, Instytut Archeologii i Etnologii PAN: 467-479.

WŁodarcZaK P., 2000. Corded Ware culture barrows in the western Little Poland. In: S. Kadrow (Ed.), A turning of ages. Im Wandel der Zeiten. Jubilee book dedicated to Professor Jan Machnik on his 70th anniversary. Kraków, Instytut Archeologii i Etnologii PAN: 481-506.

WŁodARCZAK P., 2006. Kultura ceramiki sznurowej na Wyżynie Małopolskiej. Kraków, Instytut Archeologii i Etnologii PAN.

WŁodarczaK P., 2017. Battle axes and beakers. The Final Eneolithic societies. In: P. Włodarczak (Ed.), The Past societies. 2. 5500-2000 BC. Polish lands from the first evidence of human presence to the early Middle Ages. Warszawa, Instytut Archeologii i Etnologii PAN: 275-336.

WŁodarczak P., Zastawny A., Grabowska B., 2011. Groby kultury ceramiki sznurowej i kultury mierzanowickiej ze st. 5 w Modlnicy, pow. krakowski. In: J. Kruk, A. Zastawny (Eds), Modlnica, st. 5. Od neolitu do wczesnej epoki brązu, Via Archaeologica. Źródła z badań wykopaliskowych na trasie autostrady A4 w Małopolsce. Kraków, Krakowski Zespół do Badań Autostrad: 291-410. 